\title{
Optimization of laccase production from Marasmiellus palmivorus LA1 by Taguchi method of Design of experiments
}

\author{
Aiswarya Chenthamarakshan, Nayana Parambayil, Nafeesathul Miziriya, P. S. Soumya, M. S. Kiran Lakshmi, \\ Anala Ramgopal, Anuja Dileep and Padma Nambisan*
}

\begin{abstract}
Background: Fungal laccase has profound applications in different fields of biotechnology due to its broad specificity and high redox potential. Any successful application of the enzyme requires large scale production. As laccase production is highly dependent on medium components and cultural conditions, optimization of the same is essential for efficient product production.

Results: Production of laccase by fungal strain Marasmiellus palmivorus LA1 under solid state fermentation was optimized by the Taguchi design of experiments (DOE) methodology. An orthogonal array (L8) was designed using Qualitek-4 software to study the interactions and relative influence of the seven selected factors by one factor at a time approach. The optimum condition formulated was temperature $\left(28^{\circ} \mathrm{C}\right), \mathrm{pH}(5)$, galactose $(0.8 \% \mathrm{w} / \mathrm{V})$, cupric sulphate $(3 \mathrm{mM})$, inoculum concentration (number of mycelial agar pieces) (6Nos.) and substrate length $(0.05 \mathrm{~m})$. Overall yield increase of 17.6 fold was obtained after optimization. Statistical optimization leads to the elimination of an insignificant medium component ammonium dihydrogen phosphate from the process and contributes to a 1.06 fold increase in enzyme production. A final production of $667.4 \pm 13 \mathrm{IU} / \mathrm{mL}$ laccase activity paves way for the application of this strain for industrial applications.

Conclusion: Study optimized lignin degrading laccases from Marasmiellus palmivorus LA1. This laccases can thus be used for further applications in different scales of production after analyzing the properties of the enzyme. Study also confirmed the use of taguchi method for optimizations of product production.
\end{abstract}

Keywords: Laccase, Taguchi DOE, Solid state fermentation, Marasmiellus palmivorus LA1, Optimization

\section{Background}

Laccases (EC 1.10.3.2; benzenediol: oxygen oxidoreductases) are a major group of ligninolytic enzymes which are present in all the eukaryotic kingdoms described in the five kingdom classification by R.H Whittaker in 1969 [1-5]. Laccases non-specifically catalyse one-electron oxidation of four equivalent substrates concomitant with the four-electron reduction of molecular oxygen to water with the help of a copper containing catalytic apparatus [6, 7]. Physiologically, laccase fulfil diverse roles from plant lignin polymerisation [8] to fungal morphogenesis [9]. Being less substrate specific, energy-

\footnotetext{
* Correspondence: plantbiotech1992@gmail.com Department of Biotechnology, Cochin University of Science and Technology, Cochin-22, Kerala, India
}

saving, and biodegradable, laccases were suitable in the development of highly effective, sustainable, and ecofriendly enterprises [10] in the areas of biofuel production [11], chemical transformation of xenobiotics [12], dye decolourisation [13], as biofuel cells [14], effluent treatment [15], pulp bleaching [16], as biosensors [17] and in general food quality improvement $[18,19]$. Any application of laccase requires large scale production of the me preferably in a cost effective manner.

ough other enzyme production erged fermentation, enzyme production from fungi, state fermentation (SSF) as only SSF offers an adherence surface to filamentous fungi [20]. In SSF, growth and enzyme production occur in inert or natural solid 
material under near or complete absence of free flowing liquid. SSF have advantages like high volumetric productivity [21], effective utilization of agro industrial wastes as substrates that even mimic the natural living surface of fungi and economy [22] due to its static nature. SSF utilizes materials like orange peel [23], banana waste [24], barley bran [25] and pine apple leaves [26] for useful enzyme production, which otherwise pose solid waste disposal problems. This reutilization is appreciated in the context of sustainable development. However, robust control of parameters (both media composition and cultural conditions) in SSF is difficult particularly on an industrial scale, which explains the failure of adapting successful lab scale production systems to an industrial level in the past [27]. This can be overcome by the thorough optimization of the different factors that influence production. Classical single factor method of optimization is an inadequate choice as it is time consuming [28] and will not yield any outcome regarding the relative influence of any of the involving factors. Statistical methods which also accounts for variations in the production process would be appropriate for optimization. Taguchi method of design of experiment is an approach for optimization of parameters, where the production quality stands intact even in an altered environment [29].

The Taguchi method of Design of Experiments (DOE) was developed by Genechi Taguchi who was involved in modifying the Japanese telephone system [30]. The main aim of this method is to determine the optimal process characteristic that is weakly sensitive to noise factors [31]. The taguchi method operates systematically with fewer trials, thus reducing the time, cost and effort, but offer more quantitative information [32]. The method can work even if the parameters are discrete and qualitative. It functions by reducing the sensitivity of the system [33] through thorough parameter designing. For the purpose, taguchi employs a fractional factorial design in the form of an orthogonal array. This array includes representatives from all possible combinations of selected experimental parameters, which are apt to increase the efficiency and precision and simultaneously reducing any experimental errors [34]. Analysis of individual factor contribution along with their interactive effects eventually leads to the identification of finest factors which was further optimized through Analysis of variance (ANOVA). All these advantages contribute to its greater application in other fields of science especially biotechnology.

A newly isolated strain LA1 from rarely explored species palmivorus, is the laccase producing fungus that is selected in the present study. The strain was found to be utilizing pineapple leaves, an inexpensive, unused agro-residue, as substrate for laccase production. The initial laccase activity expressed by Marasmiellus palmivorus LA1 was as good as or even higher than that of the initial activities of some of the other reported fungi [35-38]. The present study applies taguchi method for the optimization of extracellular laccase enzyme production in SSF from the fungi Marasmiellus palmivorus LA1. The experimental design comprises of seven different factors that proceeds at two levels with L8 $\left(2^{7}\right)$ array layout for laccase production. This is the first attempt reported for the optimization of laccase production from any Marasmiellus palmivorus, which is generally viewed only in the context of palm pathogens.

\section{Results and discussion}

\section{Determination of factors}

Selection of the appropriate culture factors is the prime key for the success of any optimization process. Here the factors and levels selected were based on the preliminary studies of one factor at a time (OFAT) on laccase production by Marasmiellus palmivorus LA1. The selected factors do have an influential role in laccase production as it increases the laccase production from 38.53 to $627.7 \mathrm{IU} / \mathrm{mL}$, which is 16.2 fold during OFAT. Previous studies on different fungal laccases also emphasise the requirement of temperature, $\mathrm{pH}$ [39], galactose [40], cupric sulphate [41], inoculum concentration [34], and substrate length [42] for increased laccase production. However, in OFAT only the individual factor contributions are taken into consideration, which may vary during factor interactions in an industrial scale scenario.

\section{Designing of the matrix experiment}

Taguchi method of DOE is an effective statistical plan for studying the optimization of laccase production involving several factors. It is reliable for parameter identification with the added advantage of sparing the cost. Implementation of taguchi through Qualitek-4 (QT4) windows version can be through any of the L-4 arrays with three factors at two levels to L-81 arrays with 40 factors at three levels. In the present study, the L-8 array was designed using Qualitek-4 applied in order to study seven different factors. In this orthogonal array, the control factors and the identified noise factors were varied in such a way to find out a combination where variations in noise no longer affect the overall production [43]. These were called the robust designs and the analysis is called the signal to noise ratio analysis. The signal to noise ratio is linked with quadratic loss function, which in turn assumes significant losses can happen within the specification limit [44]. Such losses within limits are expected and can easily be met. "Bigger is better" quality characteristic provides a single index for the measurable results from multiple criteria. 


\section{Experimentation of the designed matrix}

All the 8 trials were carried out under SSF. On experimenting the matrix combination, trial 5 , which comprises of temperature $-28{ }^{\circ} \mathrm{C}, \mathrm{pH}-3$, ammonium dihydrogen phosphate $-0.05 \%(\mathrm{w} / \mathrm{v})$, galactose $-0.8 \%(\mathrm{w} / \mathrm{v})$, cupric sulphate $-3 \mathrm{mM}$, inoculum concentration (number of mycelial agar pieces) - 4 Nos. and substrate length $0.05 \mathrm{~m}$ yielded maximum production with $659 \pm 12 \mathrm{IU} / \mathrm{mL}$, while least production is for the trial 1 . Trial 1 includes temperature - $26{ }^{\circ} \mathrm{C}, \mathrm{pH}-3$, ammonium dihydrogen phosphate - $0.03 \%(\mathrm{w} / \mathrm{v})$, galactose - $0.8 \%(\mathrm{w} / \mathrm{v})$, cupric sulphate $-1 \mathrm{mM}$, inoculum concentration (number of mycelial agar pieces) - 4 Nos. and substrate length $0.03 \mathrm{~m}$ (Table 1).

\section{Data analysis}

The average of obtained enzyme production, in which each factor is at given level, is described in Table 2. Difference between the average values, L2-L1 indicated the relative influence of the particular factor. Greater the difference in values, better the influence on production. The positive value indicates an increase in production as it moves from level 1 to level 2, while the negative value indicates production decrease during the course from L1 to L2. Thus among the selected factors, cupric sulphate increases the laccase production at level 2, followed by substrate length, inoculum concentration, $\mathrm{pH}$, temperature, ammonium dihydrogen phosphate and galactose. Ammonium dihydrogen phosphate has very less or no effect on laccase production with very similar values at level 1 (54.741) and level 2 (54.746). Galactose on the other hand is showing a slight better production at level 1 .

\section{Individual factor interaction}

Interaction analysis provides insight into the interaction of a factor with other factors considered during the experiment. The severity index (SI) represents the influence of two individual factors at different levels of interaction. Col. in Table 3 show the position to which interacting factors are allotted. Overall influences of the selected factors on laccase production were depicted graphically

Table 1 Experimental trial results of all the eight trials conducted

\begin{tabular}{lc}
\hline Trials & Laccase activity $(\mathrm{IU} / \mathrm{mL} \pm$ Standard deviation) \\
\hline 1 & $455.2 \pm 1$ \\
2 & $639.9 \pm 24$ \\
3 & $542 \pm 17$ \\
4 & $557 \pm 1$ \\
5 & $659 \pm 12$ \\
6 & $458 \pm 68$ \\
7 & $606.4 \pm 8$ \\
8 & $505.8 \pm 29$ \\
\hline
\end{tabular}

Table 2 Main effects of all the selected factors

\begin{tabular}{llccc}
\hline Sl. No: & Factors & Level 1 & Level 2 & L2 - L1 \\
\hline 1 & Temperature $\left({ }^{\circ} \mathrm{C}\right)$ & 54.718 & 54.769 & .05 \\
2 & $\mathrm{pH}$ & 54.662 & 54.825 & .163 \\
3 & $\mathrm{NH}_{4} \mathrm{H}_{2} \mathrm{PO}_{4}(\%)^{\mathrm{a}}$ & 54.741 & 54.746 & .005 \\
4 & Galactose $(\%)$ & 54.967 & 54.52 & -.447 \\
5 & Cupric sulphate $(\mathrm{mM})$ & 53.721 & 55.766 & 2.045 \\
6 & Inoculum concentration & 54.626 & 54.861 & .234 \\
7 & Substrate length $(\mathrm{m})$ & 54.185 & 55.302 & 1.116 \\
\hline
\end{tabular}

${ }^{\text {aPercentage against buffer }}$

(Fig. 1a-g). A perpendicular line represents full (100\%) interaction while parallel line means no interaction between the given factors. On analysing the severity index, its noteworthy that ammonium dihydrogen phosphate, the least laccase production influencer interacts maximally with inoculum concentration to give higher severity index $(89.72 \%$, Col.5), while the high enzyme production influencing cupric sulphate shows modest interaction with inoculum concentration with low SI $(0.19 \%$, Col.3).

\section{Individual factor contribution and ANOVA}

Analysis of variance test was carried out to determine the significance of individual factors on total laccase production (Table 4). Test results showed that cupric sulphate has a significant impact $(73.18 \%)$ on laccase production followed by substrate length $(23.8 \%)$. The other factors cumulatively contribute about 4.98\% only to laccase production. From the F-ratio of all selected parameters, it was noticed that ammonium dihydrogen orthophosphate has null effect on production thus its effect was pooled. Pooling also helps to avoid saturation of the designed system. All other factors and their interactions considered in the current design were statistically significant at 90\% confidence interval indicating that their variability can be explained in terms of significant effects. Contribution of each factor on laccase enzyme production was represented in Fig. 2.

\section{Optimum level determination and validation of the optimum}

The taguchi method provided optimum culture conditions for each of the influencing factor. The optimum conditions estimated and their contribution are shown in Table 5. Cupric sulphate and substrate length were the major factors affecting laccase production from Marasmiellus palmivorus LA1 under solid state fermentation. Signal to noise ratio expected was 56.769 (Table 5), from which the expected production was calculated using the formula, square root (1/Mean Square Deviation (MSD)). MSD represents all the 
Table 3 Predicted interactions of the given factors depicted via severity index

\begin{tabular}{|c|c|c|c|c|c|}
\hline SI. No: & Interacting factor pairs (Order based on SI) & Columns & SI (\%) & Col. & Opt. \\
\hline 1 & $\mathrm{NH}_{4} \mathrm{H}_{2} \mathrm{PO}_{4}(\%) \times$ Inoculum concen. & $3 \times 6$ & 89.72 & 5 & {$[1,2]$} \\
\hline 2 & Temperature $\left({ }^{\circ} \mathrm{C}\right) \times$ Inoculum concen. & $1 \times 6$ & 82.66 & 7 & {$[1,2]$} \\
\hline 3 & Temperature $\left({ }^{\circ} \mathrm{C}\right) \times$ Galactose $(\%)$ & $1 \times 4$ & 82.06 & 5 & {$[2,1]$} \\
\hline 4 & Temperature $\left({ }^{\circ} \mathrm{C}\right) \times \mathrm{NH}_{4} \mathrm{H}_{2} \mathrm{PO}_{4}(\%)$ & $1 \times 3$ & 76.01 & 2 & {$[2,1]$} \\
\hline 5 & $\mathrm{NH}_{4} \mathrm{H}_{2} \mathrm{PO}_{4}(\%) \times$ Galactose (\%) & $3 \times 4$ & 71.42 & 7 & {$[2,1]$} \\
\hline 6 & $\mathrm{pH} \times$ Inoculum concen. & $2 \times 6$ & 65.61 & 4 & {$[2,2]$} \\
\hline 7 & $\mathrm{pH} \times$ Substrate length $(\mathrm{m})$ & $2 \times 7$ & 64.67 & 5 & {$[1,2]$} \\
\hline 8 & $\mathrm{pH} \times$ Cupric sulphate $(\mathrm{mM})$ & $2 \times 5$ & 35.32 & 7 & {$[1,2]$} \\
\hline 9 & Substrate length $(\mathrm{m}) \times$ Galactose $(\%)$ & $2 \times 4$ & 34.38 & 6 & {$[2,1]$} \\
\hline 10 & $\mathrm{NH}_{4} \mathrm{H}_{2} \mathrm{PO}_{4}(\%) \times$ Substrate length $(\mathrm{m})$ & $3 \times 7$ & 28.57 & 4 & {$[2,2]$} \\
\hline 11 & $\mathrm{pH} \times \mathrm{NH}_{4} \mathrm{H}_{2} \mathrm{PO}_{4}(\%)$ & $2 \times 3$ & 23.98 & 1 & {$[2,1]$} \\
\hline 12 & Galactose (\%) x Inoculum concen. & $4 \times 6$ & 23.92 & 2 & {$[1,2]$} \\
\hline 13 & Temperature $\left({ }^{\circ} \mathrm{C}\right) \times$ Cupric sulphate $(\mathrm{mM})$ & $1 \times 5$ & 17.93 & 4 & {$[2,2]$} \\
\hline 14 & Temperature $\left({ }^{\circ} \mathrm{C}\right) \times$ Substrate length $(\mathrm{m})$ & $1 \times 7$ & 17.33 & 6 & {$[1,2]$} \\
\hline 15 & $\mathrm{NH}_{4} \mathrm{H}_{2} \mathrm{PO}_{4}(\%) \times$ Cupric sulphate $(\mathrm{mM})$ & $3 \times 5$ & 10.27 & 6 & {$[1,2]$} \\
\hline 16 & Cupric sulphate $(\mathrm{mM}) \times$ Substrate length $(\mathrm{m})$ & $5 \times 7$ & 5.15 & 2 & {$[2,2]$} \\
\hline 17 & Inoculum concen. $x$ Substrate length & $6 \times 7$ & 3.8 & 1 & {$[2,2]$} \\
\hline 18 & Temperature $\left({ }^{\circ} \mathrm{C}\right) \times \mathrm{pH}$ & $1 \times 2$ & 2.08 & 3 & {$[2,2]$} \\
\hline 19 & Galactose (\%) x Cupric sulphate $(\mathrm{mM})$ & $4 \times 5$ & 2.06 & 1 & {$[1,2]$} \\
\hline 20 & Galactose $(\%) \times$ Substrate length $(\mathrm{m})$ & $4 \times 7$ & .28 & 3 & {$[1,2]$} \\
\hline 21 & Cupric sulphate $(\mathrm{mM}) \times$ Inoculum concen. & $5 \times 6$ & .19 & 3 & {$[2,2]$} \\
\hline
\end{tabular}

Columns: Column locations to which the interacting factors are assigned, SI\%: Interaction severity index, Col: Column that should be reserved if this particular interaction is to be studied, Opt.: indicates factor levels desirable for the optimum condition

variation around the given target and can be calculated from $\mathrm{S} / \mathrm{N}$, where $\mathrm{S} / \mathrm{N}=-\log (\mathrm{MSD})$. The expected laccase production at optimum conditions was found to be $689.366 \mathrm{IU} / \mathrm{mL}$.

\section{Variation reduction plot}

Variation reduction plot is a graphical representation of the current and improved production status within upper and lower control limits (UCL or LCL) (Fig. 3). Nominal value is $553.062 \mathrm{IU} / \mathrm{mL}$ while LCL and UCL being 317.737 and $789.397 \mathrm{IU} / \mathrm{mL}$ respectively. Reduced variation is represented by the steep peak in graph. From the graph it's deducted that the improved condition could cause a savings of $37.3 \%$. This savings owes to the elimination of non necessitated media component.

\section{Validation of the optimum}

Tests were performed with the optimized factors with the recommended level. This resulted in the production of $667.4 \pm 13 \mathrm{IU} / \mathrm{mL}$ of enzyme which is comparable to the predicted $(689.366 \mathrm{IU} / \mathrm{mL})$. Thus the taguchi method is validated for extracellular laccase production.
Fungal laccase production under solid state fermentation is influenced by various environmental (temperature) and cultural $(\mathrm{pH}$, media components, substrate size, inoculum) conditions [45]. Involvement of many factors leads to optimization to improve the laccase enzyme production. Other than classical approaches, taguchi method of DOE offers a statistical design to create robustness in the process with low lost by considering only the main effects. The method also accounts multiple interaction possibilities between the parameters which is significant in industrial applications. Unlike the past decade, many works were currently relying on taguchi methods for culture parameter optimization [46], process optimization $[47,48]$, medium optimization $[49,50]$ and overall yield of enzyme production [51]. In this optimization process the most influencing factors affecting laccase production were found to be cupric sulphate, followed by substrate length and inoculum concentration. Increased production in the presence of copper can be attributed as the defensive response of fungi towards the induced metallic stress [52]. Similar increase in laccase production was observed in Marasmius quercophilus in addition of copper [53]. Copper can induce the production of laccase isozymes which 

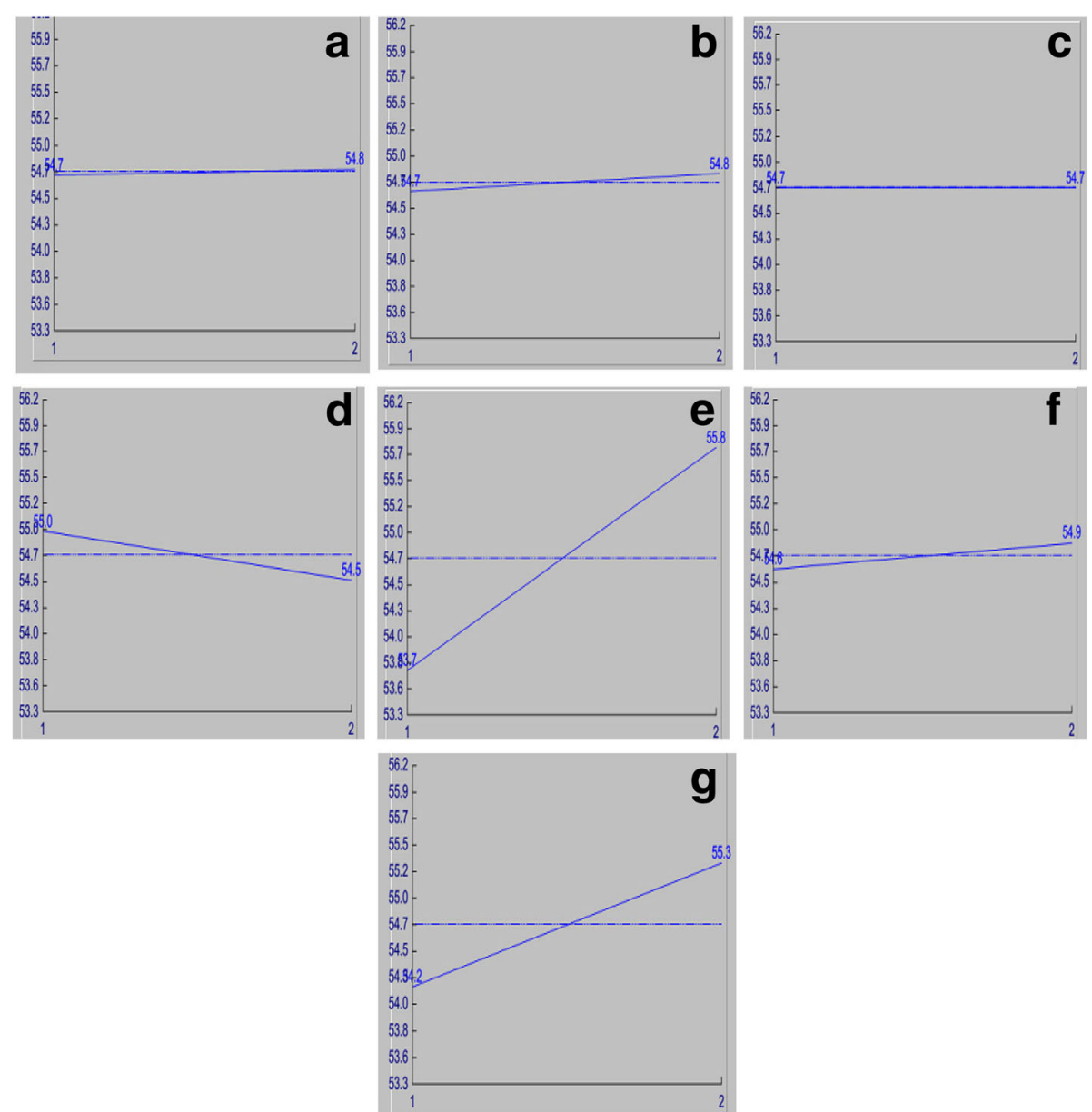

Fig. 1 Influence of the selected factors on laccase production by Marasmiellus palmivorus $L A 1$. a Temperature $\left({ }^{\circ} \mathrm{C}\right)$, b pH, $\mathbf{c}$ Ammonium dihydrogen phosphate (\%), d Galactose (\%w/v), e Cupric sulphate $(\mathrm{mM}), \mathbf{f}$ Inoculum concentration (number of mycelial agar pieces), and $\mathbf{g}$ Substrate length $(\mathrm{m})$. In all the graphs $\mathrm{X}$-axis denotes the different levels (1 and 2) of the concerned factor and Y-axis average effect of the concerned factors

leads to increased production [54]. Influence of the pine apple leaf length in production is by offering more surface area and lignin for the basidiomycete, Marasmiellus palmivorus LA1 growth and laccase production [55]. Inoculum size does play an important role in establishing the culture in Erlenmeyer flasks, which explains its influential role. The insignificance of ammonium dihydrogen phosphate in the medium was stated through the statistical study, which leads to the elimination of the same from

Table 4 Analysis of variance (ANOVA)

\begin{tabular}{llllllll}
\hline SI.No: & Factors & DOF & Sums of squares & Variance & F-Ratio & Pure Sum & Percent \\
\hline 1 & Temperature $\left({ }^{\circ} \mathrm{C}\right)$ & 1 & 0.006 & 0.006 & 173.585 & 0.006 & 0.060 \\
2 & $\mathrm{pH}$ & 1 & 0.053 & 0.053 & $1,325.232$ & 0.053 & 0.464 \\
3 & $\mathrm{NH}_{4} \mathrm{H}_{2} \mathrm{PO}_{4}(\%)$ & 1 & 0 & & POOLED & 0 & 0 \\
4 & Galactose (\%) & 1 & 0.401 & 0.401 & $10,006.075$ & 0.401 & 3.510 \\
5 & Cupric sulphate $(\mathrm{mM})$ & 1 & 8.366 & 8.366 & $208,581.269$ & 8.366 & 73.181 \\
6 & Inoculum concentration & 1 & 0.108 & 0.108 & $2,694.782$ & 0.108 & 0.945 \\
7 & Substrate length $(\mathrm{m})$ & 1 & 2.496 & 2.496 & $62,237.074$ & 2.496 & 21.835 \\
& Other/Error & 1 & 0 & 0 & & & \\
& Total & 7 & 11.433 & & & & \\
\end{tabular}




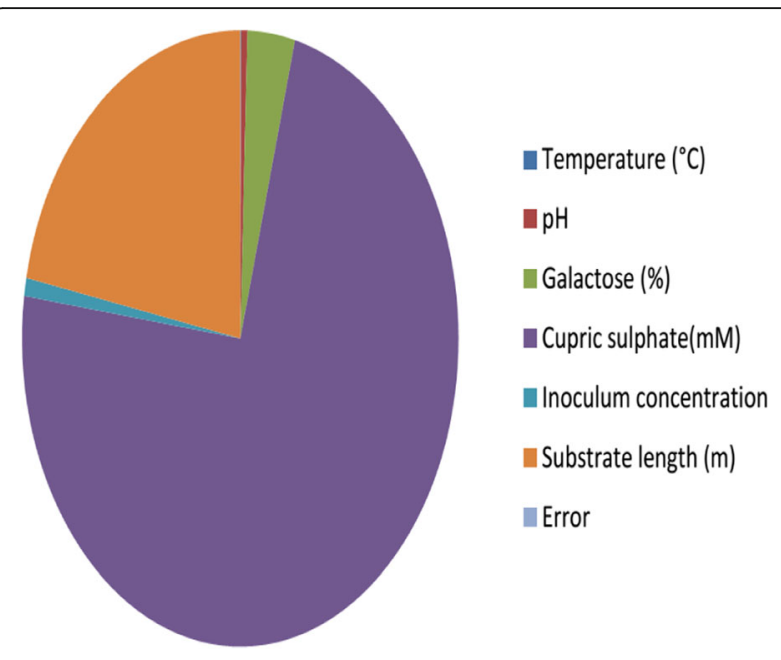

Fig. 2 Contribution of each factors on extracellular enzyme production. Cupric sulphate contributes maximum, covering a large area in the figure while ammonium dihydrogen phosphate fails to contribute any

medium, thus reducing the cost without compromising the production quality and quantity. The strain provides a satisfactory yield of laccase (Table 6) leading to the application of the enzyme directly or in immobilized form in industrial settings.

\section{Conclusion}

Optimization of laccase production under solid state fermentation by Marasmiellus palmivorus LA1 stain was done via taguchi method of DOE using Qualitek-4. The study aided in the understanding of individual factor contribution and interaction among factors. Elimination of unwanted factors significantly reduce the loss during the process, which otherwise needed to be met. Validation of optimized parameters provides an optimum set of conditions that are insensitive to noise factors which can be used in large scale bioprocess.

Table 5 Optimum culture condition predicted and their contributions on the selected levels

\begin{tabular}{lllll}
\hline Sl. No: & Factors & Level description & Level & Contribution \\
\hline 1 & Temperature $\left({ }^{\circ} \mathrm{C}\right)$ & 28 & 2 & 0.025 \\
2 & $\mathrm{pH}$ & 5 & 2 & 0.081 \\
3 & Galactose $(\%)$ & 0.8 & 1 & 0.223 \\
4 & Cupric sulphate $(\mathrm{mM})$ & 3 & 2 & 1.023 \\
5 & Inoculum concentration & 6 & 2 & 0.117 \\
6 & Substrate length (m) & 0.05 & 2 & 0.558 \\
Total contribution from all factors & & 2.025 \\
Current grand average of performance & & 54.743 \\
Expected result at optimum condition & & 56.769 \\
\hline
\end{tabular}

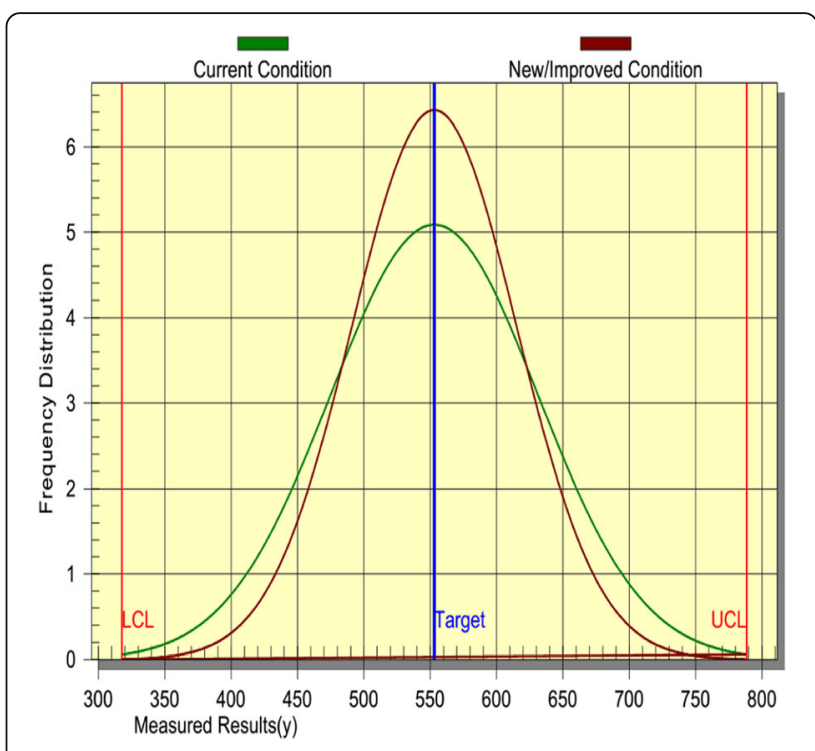

Fig. 3 Variation reduction plot based on current and new, improved conditions. Normal performance distribution profiles for laccase activity with higher improved frequency

\section{Methods}

\section{Microorganism}

For the present study, the culture of fungi Marasmiellus palmivorus LA1 isolated from Palakkad district of Kerala, India was used for the production of extra cellular laccases. The strain was grown and then maintained on Potato dextrose agar (PDA) at $4{ }^{\circ} \mathrm{C}$.

\section{Solid state fermentation for enzyme production}

Pineapple leaves of varying length were used as the substrate [26], onto which Marasmiellus palmivorus LA1 mycelial agar pieces $(0.005 \mathrm{~m} \times 0.005 \mathrm{~m}$ sized $)$ were inoculated in $250 \mathrm{~mL}$ Erlenmeyer flask. The moisture content was adjusted to $10 \%$ with $0.1 \mathrm{M}$ sodium citrate buffer of $\mathrm{pH} 5$. The system was incubated for 5 days under static condition in appropriate temperatures.

\section{Product extraction}

Extracellular enzyme was extracted using $40 \mathrm{~mL}$ of $0.1 \mathrm{M}$ sodium citrate buffer of $\mathrm{pH} 5$. After incubation period, the mycelial-free supernatant was collected by gentle shaking followed by centrifugation at $9000 \mathrm{~g}$ for $10 \mathrm{~min}$ and used for further laccase activity assays.

\section{Enzyme assay}

The laccase assay was performed spectrophotometrically (Shimadzu 1601) at $420 \mathrm{~nm}$ using 2,2'-azino-bis (3-ethylbenzothiazoline-6-sulphonic acid) (ABTS) as substrate [56]. One unit $(\mathrm{IU} / \mathrm{mL})$ of laccase activity was defined as the amount of enzyme required for the conversion of one micromole of substrate per minute under assay conditions. 
Table 6 Comparison of laccase yields of other fungi with the fungus of interest, grown under solid state fermentation

\begin{tabular}{|c|c|c|c|c|}
\hline SI. No: & Organism & Substrate & Enzyme activity (IU/mL) & Reference \\
\hline 1 & Pleurotus ostreatus & Banana pseudostem & 3 & [58] \\
\hline 2 & Pleurotus sajor-caju. & Banana pseudostem & 3.6 & [58] \\
\hline 3 & Coprinellus disseminatus SW-1 NTCC 1165 & Wheat bran & 25.5 & [59] \\
\hline 4 & Aspergillus heteromorphus & Rice straw & 6.6 & [60] \\
\hline 5 & Aspergillus heteromorphus & Sugarcane baggase & 2.9 & {$[60]$} \\
\hline 6 & Schizophyllum commune IBL-06 & Banana stalks & 345 & [61] \\
\hline 7 & Ganoderma lucidum & Pineapple leaf & $472.31 \pm 41.2$ & [26] \\
\hline 8 & Coculture of Pleurotus flabellatus and Pleurotus eous & Coffee pulp & 8.8 & {$[62]$} \\
\hline 9 & Schyzophyllum commune & Corn stover & 130.80 & [63] \\
\hline 10 & Pleurotus ostreatus IBL-04 & Wheat straw & $517 \pm 1.05$ & [64] \\
\hline 11 & Phanerochaete chrysosporium & Wheat straw & 263.03 & {$[65]$} \\
\hline 12 & Trametes versicolor IBL-04 & Corn cobs & 869.65 & {$[66]$} \\
\hline 13 & Marasmiellus palmivorus LA1 & Pine apple leaf & $667.4 \pm 13$ & Present study \\
\hline
\end{tabular}

\section{Taguchi method for optimization}

In the present study, the taguchi method of optimization moves in five stages: factors determination, matrix designing, experimentation of matrix, data analysis and optimum level validation. All these stages proceed in a stepwise manner to finally yield a valid output.

\section{Determination of factors}

Using the one factor at a time (OFAT) method for optimization seven different factors that were found to be crucial for laccase enzyme production in Marasmiellus palmivorus LA1 were listed out. Then these factors were used for further optimization using taguchi method. The significant influencing factors are temperature, $\mathrm{pH}$, ammonium dihydrogen phosphate $\left(\mathrm{NH}_{4} \mathrm{H}_{2} \mathrm{PO}_{4}\right)$, galactose, cupric sulphate, inoculum concentration (number of mycelial agar pieces) and substrate length.

\section{Designing of the matrix experiment}

QUALITEK-4 software (Nutek Inc., MI, USA) was employed for the purpose [57]. Using an L8 $\left(2^{7}\right)$ orthogonal array the seven major factors were studied in two levels (Table 7). "Bigger is better" was the

Table 7 Selected culture factors and their assigned levels

\begin{tabular}{llll}
\hline SI.No: & Factors & Level 1 & Level 2 \\
\hline 1 & Temperature $\left({ }^{\circ} \mathrm{C}\right)$ & 26 & 28 \\
2 & $\mathrm{pH}$ & 3 & 5 \\
3 & $\mathrm{NH}_{4} \mathrm{H}_{2} \mathrm{PO}_{4}(\%)$ & 0.03 & 0.05 \\
4 & Galactose (\%) & 0.8 & 1.2 \\
5 & Cupric sulphate $(\mathrm{mM})$ & 1 & 3 \\
6 & Inoculum concentration & 4 & 6 \\
7 & Substrate length $(\mathrm{m})$ & 0.03 & 0.05 \\
\hline
\end{tabular}

quality characteristic preferred in the experimental studies. Signal to noise ratio analysis was used for result analysis.

\section{Experimentation of the designed matrix}

Based on the two levels mentioned (Table 7) 8 different trial sets of solid state fermentation were conducted with Marasmiellus palmivorus LA1 (Table 8). All the trials were performed in $250 \mathrm{~mL}$ Erlenmeyer flasks having pine apple leaves of length 0.03 or $0.05 \mathrm{~m}$ (depending on the assigned levels) wetted with $\mathrm{pH} 3$ or 5 sodium citrate buffer $(0.1 \mathrm{M})$. Ammonium dihydrogen phosphate $(0.03 \%$ or $0.05 \%(w / v))$ and galactose $(0.8 \%$ or $1.2 \%(\mathrm{w} / \mathrm{v}))$ were dissolved in the buffer and supplemented. Filter sterilized cupric sulphate was added after autoclaving of the flasks at $121{ }^{\circ} \mathrm{C}, 1.03$ bar pressure for $20 \mathrm{~min}$. Variation in the inoculum concentration was created by using different number of agar pieces ( 4 or 6 ). $26{ }^{\circ} \mathrm{C}$ or $28{ }^{\circ} \mathrm{C}$ temperature was maintained throughout the period of 5-day incubation. Enzyme extraction was performed

Table $8 \mathrm{~L}-8$ orthogonal array design

\begin{tabular}{llllllll}
\hline Trials & \multicolumn{7}{l}{ Columns } \\
\cline { 2 - 7 } & 1 & 2 & 3 & 4 & 5 & 6 & 7 \\
\hline Trial 1 & 1 & 1 & 1 & 1 & 1 & 1 & 1 \\
Trial 2 & 1 & 1 & 1 & 2 & 2 & 2 & 2 \\
Trial 3 & 1 & 2 & 2 & 1 & 1 & 2 & 2 \\
Trial 4 & 1 & 2 & 2 & 2 & 2 & 1 & 1 \\
Trial 5 & 2 & 1 & 2 & 1 & 2 & 1 & 2 \\
Trial 6 & 2 & 1 & 2 & 2 & 1 & 2 & 1 \\
Trial 7 & 2 & 2 & 1 & 1 & 2 & 2 & 1 \\
Trial 8 & 2 & 2 & 1 & 2 & 1 & 1 & 2 \\
\hline
\end{tabular}


as previously described. All the trials were performed in triplicates.

\section{Data analysis}

Analysis of the obtained results was done using Qualitek-4 software to infer the interactions between different factors and to give idea about the influence of each individual factor on enzyme production.

\section{Optimum level determination and validation of the optimum}

By analysing the interactions, the software predicts an optimum condition for maximum enzyme production. The software recommended optimum condition was validated by conducting solid state fermentation and assay testing in triplicates under the optimum condition.

\section{Abbreviations}

ABTS: 2, 2'-azino-bis (3-ethylbenzothiazoline-6-sulphonic acid); ANOVA: Analysis of variance; DOE: Design of experiments; LSL: Lower specification limit; MSD: Mean square deviation; OFAT: One factor at a time; PDA: Potato dextrose agar; SI: Severity index; SSF: Solid state fermentation; USL: Upper specification limit

\section{Acknowledgment}

The authors gratefully acknowledge Department of Biotechnology, Cochin University of Science and Technology, Cochin -22 for the facilities and infrastructure, and Kerala State Council for Science Technology and Environment (KSCSTE) for the financial assistance.

\section{Funding}

The fund to carry out the work was provided by Kerala state council for science, technology and environment (KSCSTE), Trivandrum, Kerala, India in the form of junior research fellowships. KSCSTE played no role in the design of the study, the collection, analysis, and interpretation of data or in writing the manuscript.

\section{Availability of data and materials}

The organism was isolated, identified, maintained and studied in Plant Biotechnology Laboratory, Cochin University of science and technology. The data generated regarding the identification was available in Genbank with accession number KP125487.

\section{Authors' contributions}

AC identified the fungus, participated in the design of the study, solid state fermentation experiments, statically interpretation and drafted revised the manuscript. NP, NM, SPS participated in helping solid state fermentation experiments. KLMS, AR participated in helping statistical interpretation. AD participated in helping the manuscript drafting and revision. PN conceived of the study, participated in its design, co-ordinated the work and carefully revised the manuscript. All authors read and approved the final manuscript.

\section{Authors' information}

Aiswarya Chenthamarakshan received her M.Sc Biotechnology from Department of Biotechnology, Cochin University of Science and Technology, Cochin 22 in 2013 and currently pursuing Ph.D under the guidance of Dr. Padma Nambisan in Plant Biotechnology Laboratory, Cochin University of Science and Technology. Her interests are in utilization of laccase producing fungi for industrial applications.

Nayana parambayil studied M.Sc Biotechnology in Department of Biotechnology, Cochin University of Science and Technology and presently doing Ph.D under the guidance of Dr. Padma Nambisan in Plant Biotechnology Laboratory. She mainly focuses on solid state fermentation of ligninases. Nafeesathul Miziriya is currently studying M.Sc Biotechnology in Department of Biotechnology, Cochin University of Science and Technology and joins the group as a summer trainee. Her research interests are in the field of fungal enzymes.
Soumya P S pursued M.Sc. Biotechnology, from Bharathiar University, Tamilnadu and presently working in Plant Biotechnology Laboratory as a Ph.D scholar. Her area of study was laccases and their potential applications.

Kiran Lakshmi M S studied Gene Technology from J.J. College of Arts and Science, Tamil nadu, India where she got her master's degree, and joined Dr. Padma Nambisan in 2012 for her doctoral degree. Her area under study includes molecular biology of ligninolytes.

Anala Ramgopal is a Ph.D student working under Dr. Padma Nambisan in Plant Biotechnology Laboratory of Cochin University of Science and Technology. She completed her master's degree from Cochin University of Science and Technology in biotechnology. Biodegradation of polythene is her major area of interest.

Anuja Dileep after finishing her M.Sc. Biotechnology joined Plant Biotechnology Laboratory, Cochin University of Science and Technology in 2014. Her interests include effluent treatment using biological methods. Dr. Padma Nambisan is currently working as a faculty (Professor and guide) in Department of Biotechnology, Cochin University of science and technology. She achieved Post Doctoral DBT Fellowship from Indian Institute of Science and Ph.D from Indian Agricultural Research Institute (I.A.R.I). Her major area of expertise includes Plant Biotechnology and Genetics and fungal biotechnology.

\section{Competing interests}

The authors declare that they have no competing interests.

\section{Consent for publication}

Not applicable.

\section{Ethics approval and consent to participate}

The fungus was originally collected from decaying wood found freely in nature and thus do not require compliance with any guidelines. All the other studies on the fungus was in compliance with the national guidelines.

Received: 10 August 2016 Accepted: 7 February 2017

Published online: 13 February 2017

\section{References}

1. Ranocha P, McDougall G, Hawkins S, Sterjiades R, Borderies G, Stewart D, Cabanes-Macheteau M, Boudet AM, Goffner D. Biochemical characterization, molecular cloning and expression of laccases-a divergent gene family-in poplar. Eur J Biochem. 1999;259(1-2):485-95.

2. Bourbonnais $R$, Paice $M G$, Reid ID, Lanthier $P$, Yaguchi M. Lignin oxidation by laccase isozymes from Trametes versicolor and role of the mediator 2, 2'azinobis (3-ethylbenzthiazoline-6-sulfonate) in kraft lignin depolymerization. Appl Environ Microb. 1995;61(5):1876-80.

3. Sharma P, Goel R, Capalash N. Bacterial laccases. World J Microb Biot. 2007:23(6):823-32.

4. Arora DS, Sharma RK. Ligninolytic fungal laccases and their biotechnological applications. Appl Biochem Biotech. 2010;160(6):1760-88.

5. Tartar A, Wheeler MM, Zhou X, Coy MR, Boucias DG, Scharf ME. Parallel metatranscriptome analyses of host and symbiont gene expression in the gut of the termite Reticulitermes flavipes. Biotechnol Biofuels. 2009;2(1):1.

6. Solomon El, Sundaram UM, Machonkin TE. Multicopper oxidases and oxygenases. Chem Rev. 1996;96(7):2563-606

7. Messerschmidt A. Spatial structures of ascorbate oxidase, laccase and related proteins: implications for the catalytic mechanism. In: Messerschmidt A, editor. Multi-copper oxidases. Singapore: World Scientific; 1997. p. 23-80.

8. Sterjiades R, Dean JF, Eriksson KE. Laccase from sycamore maple (Acer pseudoplatanus) polymerizes monolignols. Plant Physiol. 1992;99(3):1162-8.

9. Leatham GF, Stahmann MA. Studies on the laccase of Lentinus edodes: specificity, localization and association with the development of fruiting bodies. Microbiology. 1981;125(1):147-57.

10. Osma JF, Toca-Herrera JL, Rodríguez-Couto S. Uses of laccases in the food industry. Enzyme Res. 2010;2010:1-8.

11. Kudanga T, Le Roes-Hill M. Laccase applications in biofuels production: current status and future prospects. Appl Microbiol Biot. 2014;98(15):6525-42.

12. Calvo AM, Copa-Patiño JL, Alonso O, González AE. Studies of the production and characterization of laccase activity in the basidiomycete Coriolopsis gallica, an efficient decolorizer of alkaline effluents. Arch Microbiol. 1998; 171(1):31-6. 
13. Khlifi R, Belbahri L, Woodward S, Ellouz M, Dhouib A, Sayadi S, Mechichi T. Decolourization and detoxification of textile industry wastewater by the laccase-mediator system. J Hazard Mater. 2010;175(1):802-8.

14. Slomczynski D, Nakas J, Tanenbaum SW. Production and Characterization of Laccase from Botrytis cinerea 61-34. Appl Environ Microb. 1995;61(3):907-12.

15. Jaouani A, Guillén F, Penninckx MJ, Martínez AT, Martínez MJ. Role of Pycnoporus coccineus laccase in the degradation of aromatic compounds in olive oil mill wastewater. Enzyme Microb Tech. 2005;36(4):478-86.

16. Luisa M, Goncalves FC, Steiner W. Use of laccase for bleaching of pulps and treatment of effluents. In: Enzymes for pulp and paper processing. 1996. p. 197-206.

17. Montereali MR, Della Seta L, Vastarella W, Pilloton R. A disposable LaccaseTyrosinase based biosensor for amperometric detection of phenolic compounds in must and wine. J Mol Catal B-Enzym. 2010;64(3):189-94.

18. Selinheimo E, Kruus K, Buchert J, Hopia A, Autio K. Effects of laccase, xylanase and their combination on the rheological properties of wheat doughs. J Cereal Sci. 2006;43(2):152-9.

19. Neifar M, Ellouze-Ghorbel RA, Kamoun A, Baklouti S, Mokni A, Jaouani A, Ellouze-Chaabouni SE. Effective clarification of pomegranate juice using laccase treatment optimized by response surface methodology followed by ultra filtration. J Food Process Eng. 2011;34(4):1199-219.

20. Pandey A. Solid-state fermentation. Biochem Eng J. 2003;13(2):81-4.

21. Duenas R, Tengerdy RP, Gutierrez-Correa M. Cellulase production by mixed fungi in solid-substrate fermentation of bagasse. World J Microb Biot. 1995;11(3):333-7.

22. Murugesan K, Nam IH, Kim YM, Chang YS. Decolorization of reactive dyes by a thermostable laccase produced by Ganoderma lucidum in solid state culture. Enzyme Microb Tech. 2007;40(7):1662-72.

23. Rosales E, Couto SR, Sanromán MA. Increased laccase production by Trametes hirsuta grown on ground orange peelings. Enzyme Microb Tech. 2007;40(5):1286-90.

24. Elisashvili V, Parlar H, Kachlishvili E, Chichua D, Bakradze M, Kokhreidze N, Kvesitadze G. Ligninolytic activity of basidiomycetes grown under submerged and solid-state fermentation on plant raw material (sawdust of grapevine cuttings). Adv Food Sci. 2001;23(3):117-23.

25. Couto SR, Gundín M, Lorenzo M, Sanromán MÁ. Screening of supports and inducers for laccase production by Trametes versicolor in semi-solid-state conditions. Process Biochem. 2002;38(2):249-55.

26. Hariharan S, Nambisan P. Optimization of lignin peroxidase, manganese peroxidase, and Lac production from Ganoderma lucidum under solid state fermentation of pineapple leaf. BioResources. 2012;8(1):250-71.

27. Cen P, Xia L. Production of cellulase by solid-state fermentation. In: Tsao GT, editor. Recent Progress in Bioconversion of Lignocellulosics. Berlin Heidelberg: Springer; 1999. p. 69-92.

28. Silva EM, Rogez H, Larondelle Y. Optimization of extraction of phenolics from Inga edulis leaves using response surface methodology. Sep Purif Technol. 2007:55(3):381-7.

29. Khuri Al, Mukhopadhyay S. Response surface methodology. WIREs Comp Stat. 2010;2(2):128-49.

30. Martínez-Lorente AR, Dewhurst F, Dale BG. Total quality management: origins and evolution of the term. TQM Mag. 1998;10(5):378-86.

31. Montgomery DC. Design and analysis of experiments. New Jersey: Wiley; 2008

32. Stone RA, Veevers A. The Taguchi influence on designed experiments. J Chemometr. 1994;8(2):103-10.

33. Yang WP, Tarng YS. Design optimization of cutting parameters for turning operations based on the Taguchi method. J Mater Process Tech. 1998;84(1):122-9.

34. Prasad KK, Mohan SV, Rao RS, Pati BR, Sarma PN. Laccase production by Pleurotusostreatus 1804: Optimization of submerged culture conditions by Taguchi DOE methodology. Biochem Eng J. 2005;24(1):17-26.

35. Boehmer U, Suhardi SH, Bley T. Decolorizing reactive textile dyes with whiterot fungi by temporary immersion cultivation. Eng Life Sci. 2006;6(4):417-20.

36. Stajić M, Persky L, Friesem D, Hadar Y, Wasser SP, Nevo E, Vukojević J. Effect of different carbon and nitrogen sources on laccase and peroxidases production by selected Pleurotus species. Enzyme Microb Tech. 2006;38(1):65-73.

37. Mohorčič M, Friedrich J, Pavko A. Decoloration of the diazo dye reactive black 5 by immobilized Bjerkandera adusta in a stirred tank bioreactor. Acta Chim Slov. 2004;51:619-28.

38. Gnanamani A, Jayaprakashvel M, Arulmani M, Sadulla S. Effect of inducers and culturing processes on laccase synthesis in Phanerochaete chrysosporium NCIM 1197 and the constitutive expression of laccase isozymes. Enzyme Microb Tech. 2006;38(7):1017-21.
39. Nyanhongo GS, Gomes J, Gübitz G, Zvauya R, Read JS, Steiner W. Production of laccase by a newly isolated strain of Trametes modesta. Bioresource Technol. 2002;84(3):259-63.

40. Elshafei AM, Hassan MM, Haroun BM, Elsayed MA, Othman AM. Optimization of laccase production from Penicillium martensii NRC 345. Adv life sci. 2012;2(1):31-7.

41. Revankar MS, Lele SS. Enhanced production of laccase using a new isolate of white rot fungus WR-1. Process Biochem. 2006:41(3):581-8.

42. Patel H, Gupte A, Gupte S. Effect of different culture conditions and inducers on production of laccase by a basidiomycete fungal isolate Pleurotus ostreatus HP-1 under solid state fermentation. BioResources. 2009;4(1):268-84.

43. Farnet AM, Tagger S, Le Petit J. Effects of copper and aromatic inducers on the laccases of the white-rot fungus Marasmius quercophilus. $\mathrm{Cr}$ Acad Sci IIIVIE. 1999:322(6):499-503.

44. Joglekar AM. Statistical methods for six sigma: in R\&D and manufacturing. USA: Wiley; 2003.

45. Niku-Paavola ML, Karhunen E, Kantelinen A, Viikari L, Lundell T, Hatakka A. The effect of culture conditions on the production of lignin modifying enzymes by the white-rot fungus Phlebia radiata. J Biotechnol. 1990;13(2):211-21.

46. Sabarathinam S, Jayaraman V, Balasubramanian M, Swaminathan K. Optimization of culture parameters for hyper laccase production by Trichoderma asperellum by Taguchi design experiment using L-18 orthogonal array. Malaya j Biosci. 2014;1(4):214-25.

47. El Aty AA, Wehaidy HR, Mostafa FA. Optimization of inulinase production from low cost substrates using Plackett-Burman and Taguchi methods. Carbohyd Polym. 2014;102:261-8.

48. Mnif I, Sahnoun R, Ellouze-Chaabouni S, Ghribi D. Evaluation of B. subtilis SPB1 biosurfactants' potency for diesel-contaminated soil washing: optimization of oil desorption using Taguchi design. Environ Sci Pollut R. 2014;21(2):851-61

49. Petlamul W, Prasertsan P. Medium optimization for production of Beauveriabassiana BNBCRC spores from biohydrogen effluent of palm oil mill using taguchi design. Int J Biosci Biochem Bioinforma. 2014:4(2):106.

50. Kamble R, Gupte A. Cyclodextrin glycosyltransferase production by alkaliphilic bacillus sp. Isolated from rice cultivated soil and media optimization using taguchi method. Int J Pharm Sci Res. 2014;5(7):2754.

51. Azin M, Moravej R, Zareh D. Production of xylanase by Trichoderma longibrachiatum on a mixture of wheat bran and wheat straw: Optimization of culture condition by Taguchi method. Enzyme Microb Tech. 2007; 40(4):801-5.

52. Fernandez-Larrea J, Stahl U. Isolation and characterization of a laccase gene from Podospora anserina. Molec Gen Genet. 1996;252(5):539-51.

53. Rao RS, Kumar CG, Prakasham RS, Hobbs PJ. The Taguchi methodology as a statistical tool for biotechnological applications: a critical appraisal. Biotechnol J. 2008;3(4):510-23.

54. Saparrat MC, Guillén F, Arambarri AM, Martínez AT, Martínez MJ. Induction, isolation, and characterization of two laccases from the white rot basidiomycete Coriolopsis rigida. Appl Environ Microb. 2002;68(4):1534-40.

55. Mishra S, Mohanty AK, Drzal LT, Misra M, Hinrichsen G. A review on pineapple leaf fibers, sisal fibers and their biocomposites. Macromol Mater Eng. 2004;289(11):955-74.

56. Bourbonnais $R$, Leech D, Paice MG. Electrochemical analysis of the interactions of laccase mediators with lignin model compounds. BBA-Gen Subjects. 1998;1379(3):381-90.

57. Montgomery DC. Introduction to statistical quality control. 2nd ed. Wiley; 1991.

58. Ghosh M, Mukherjee R, Nandi B. Production of extracellular enzymes by two Pleurotus species using banana pseudostem biomass. Acta Biotechnol. 1998;18(3):243-54

59. Agnihotri S, Dutt D, Tyagi CH, Kumar A, Upadhyaya JS. Production and biochemical characterization of a novel cellulase-poor alkali-thermo-tolerant xylanase from Coprinellus disseminatus SW-1 NTCC 1165. World J Microb Biot. 2010;26(8):1349-59.

60. Singh A, Bajar S, Bishnoi NR, Singh N. Laccase production by Aspergillus heteromorphus using distillery spent wash and lignocellulosic biomass. J Hazard Ma Ter. 2010;176(1):1079-82.

61. Irshad M, Asgher M. Production and optimization of ligninolytic enzymes by white rot fungus Schizophyllum commune IBL-06 in solid state medium banana stalks. Afr J Biotechnol. 2011;10(79):18234-42.

62. Parani K, Eyini M. Production of ligninolytic enzymes during solid state fermentation of coffee pulp by selected fungi. Sci Res Rep. 2012;2(3):202-9. 
63. Yasmeen Q, Asgher M, Sheikh MA, Nawaz H. Optimization of ligninolytic enzymes production through response surface methodology. BioResources. 2013;8(1):944-68.

64. Asgher M, Ahmad Z, labal HM. Alkali and enzymatic delignification of sugarcane bagasse to expose cellulose polymers for saccharification and bio-ethanol production. Ind Crop Prod. 2013:44:488-95.

65. Koyani RD, Sanghvi GV, Sharma RK, Rajput KS. Contribution of lignin degrading enzymes in decolourisation and degradation of reactive textile dyes. Int Biodeter Biodegr. 2013;77:1-9.

66. Noreen S, Asgher M, Hussain F, lqbal A. Performance Improvement of Ca-Alginate Bead Cross-Linked Laccase from Trametes versicolor IBL-04. North Carolina: BioResources. 2015;11(1):558-72.

Submit your next manuscript to BioMed Central and we will help you at every step:

- We accept pre-submission inquiries

- Our selector tool helps you to find the most relevant journal

- We provide round the clock customer support

- Convenient online submission

- Thorough peer review

- Inclusion in PubMed and all major indexing services

- Maximum visibility for your research

Submit your manuscript at www.biomedcentral.com/submit
Biomed Central 